\title{
Adyghe (Circassian) Religiosity and its Reproduction in Contemporary Prose
}

\author{
S.A. Kirzhinova ${ }^{1}$, L.K. Bzegezheva, M.K. Bolokova, F.N. Huako \\ ${ }^{\text {I}}$ Maikop State Technological University, Pervomayskaya Street, 191, Maikop, 385000, Republic of Adygeya, Russia \\ *Corresponding author E-mail: kirzhinova.s.a@mail.ru
}

\begin{abstract}
Article considers Adyghe (Circassian) religiosity and its reproduction in contemporary prose. Conducted study and a variety of problems in this case are rare, besides, almost complete cancellation of any research activity in today's Russia is known. And the problems are not studied enough. Therefore, the relevance of the selected topic is undoubtedly important, and we are developing it using a number of analytical and synthetic methods inherent in humanitarian knowledge. In the course of research, we established that the fact that both religions common today (Christianity, Islam) are not at all sources of interethnic difficulties, and concluded that the state must strive to support the existing religious branches (in particular, Islam and Christianity). The relevance of this work is that the problems in this field are too little studied, and our research provides new data, as well as a new look at this topic.
\end{abstract}

Keywords: Adyghe; Adyghe tribes; Allah; Belief; Caucasus; Ceremony; God; Islam; Religion; Religiosity; Ritual.

\section{Introduction}

In the spaces of the global (both strategic and financial) transformations of the current century, the place of the Caucasian territories on world maps is much more palpable. Prolonged mutual influence in the North Caucasus area by ethnic, tribal and religious factors in the chronicle process predetermined a specific phenomenon. Throughout the centuries, there was a gradual infusion of sacred jets in Highland literature. It has been occurred as a result of the long-lasting filling of reality by religion, and religiosity - the consciousness of the Highland people. Moreover, Russia, a priori, refers to that significant number of states in which secular ideology is virtually formal one. In fact, the impact of religious motives on minds and souls, as well as on the policy being built, is quite palpable. Despite the almost century-long duration of the strictly atheistic power that prevailed here, of which one of the Adyghe authors being analyzed today is Aitech Khagurov said "A little time will pass after the end of the war and these party-komsomol activists will start again a war with religion, threatening not cold water, but cold Siberia" [1]. Categorically denying any god, it never made the avoiding of religion from politics, in the country, which can be feasibly in the modern Western world.

The concept of the mutual impact of ethnic and sacred components was formed and strengthened in the intellection of the representatives of nations for many centuries. In fact, in the process of obtaining knowledge, the intersection of the sociocultural sector with religion can be a starting source. He is appointed to lead the individual to a sacred perception of the essence of the usual concepts. According to acclaimed Soviet-era scholar S.P. Capitsa, "Essentially, after all, science has grown out of religion" [2]. As stated Edward Spencer (British traveler of the XVI century), on this occasion "In addition to the one eternal God, they believe in the existence of several lower beings or saints, to whom the Great Spirit, Tha, has transferred power over such earthly things, that he considers too insignificant for his fearinspiring control... Some of them are a special symbol; but they do not worship them otherwise than as an intermediate object. On this score, I conducted a rigorous survey and found that all my informants agreed with this opinion and confirmed what I had heard before from several Russian officers, who for many years had been associated with the Circassians... This worship should be considered a kind of adoration of a strict Protestant and an equally strict Muslim" [3]. Available in the nation's customs and rituals, the concepts and representations that are put on the confession are treated as those sent by the Most High and bearing the religious essence. In particular, Islam is the most prominent religion for Adyghes and in the North Caucasus area. The individual attribution to it is usually correlated with the corresponding self-identification, i.e. in most cases Adyghe will say: "I - a Muslim" and clarify "As prompted by the ancestors". However, some scholars do not agree directly to relate religious affiliation to ethnic identification. Thus, according to R.A. Lopatkin, "the fact of person's confessional self-identification does not always indicate his religiosity" [4]. And S.P. Kapitsa, who relates himself to Orthodox atheism, confirms this: "I can talk about God as a cultural phenomenon, but I believe that our misunderstanding of certain things does not mean the presence of God".

Sometimes this fact leads to the manifestation in the minds of ethnic representatives of chauvinistic components. Moreover, the complete religion denial, ignoring the rites handed down by the generations, is explained and called the withdrawal from the ethnos. In general, the traditional character of ethnic beliefs is a significant mechanism for combining the ancient and the current, which acts on many levels of society. Faith, as well as religious thinking, is established phenomena in the cultures of peoples. An illustration of this can be a phrase from the text of one of the Adyghe authors Mukhaddin Kandur, analyzed by us: "When the burial ground was buried, the mullah began to sing in chanting prayers from the Koran and other ancient sacred books, which he 
himself never read, but fragments from which traditionally kept in memory" [5].

However, thoughtful traditional nature is capable to interchange with pathos expressiveness in this subject. According to the modern Adyghe author Amir Makoyev, "It is impossible, even for a moment, to believe that our intellect, soul and conscience were indifferent to the Creator" [6]. And this phrase appears in the narrator pending of complains about the lack of their own vital productivity: "I live for exactly one thousand years. Time goes by, but I do not do anything significant. And if I take on something, I soon tie it up, there is no strength, and no desire to complete it, all interest disappears. It's like in a dream - in an unaccustomed, sticky mass, your legs and hands are stuck, and you wake up all in a sweat, tired of a senseless struggle for your ghostly life" [6].

These phenomena have spent tools and technologies of a number of denominations, which can be attributed to the ideologies of the most common groups in the world community. According to a number of censuses, which are already conducted in the new century, the domestic religious attitude is characterized by an obvious feature - the preference of the Muslim peoples by the peoples of the Caucasus. According to M.Z. Magomedova, who citing data by the period of the census of 2006-2008, in the framework of the Program of Basic Research of the Presidium of the Russian Academy of Sciences, "The census singled out 20 indigenous Islamists of the Caucasus as separate ethnic groups (Kabardians, Circassians, Adyghes, Shapsugs, Abasins, Chechens, Ingushs, Avars, Laks, Dargins, Lezgins, Tabasarans, Aghul, Rutulians, Tsakhurs, Karachais, Balkars, Kumyks, Nogai, Hemshili)" [7].

It is necessary to emphasize here a certain defect of the Dagestan scientist: the Kabardins, Circassians, Adyghes, Shapsugs, Abasins, which she classifies as Aboriginal peoples, belong to the same Adygeyan ethnos. Kabardinians, Shapsugs, Abazins are Adyghes tribes. "Adyghes» - only the Soviet name of the inhabitants of the Adyghe Autonomous Region, and the "Circassians" - the exonym of the Adyghe people. Thus, according to the results of this census, the ethnic groups which are professing Islam are not twenty, but fifteen. But, in any case, more than ten. According to the above mentioned data, national-faith elements are seen most prominently in the republican regions of the Caucasus, which can be explained by a concrete cause-and-effect line. The Russian national policy, which is in force today, extend the line of ongoing and expressed alienation of the so-called. "Non-Russian" nations and religions, given by the president in his statements about "chocks." Consequently, the Caucasian, or more precisely (especially) Adyghe ethnic features in the country are practically not covered, the people are simply attributed as "young written" and inconspicuous. Careful study and a variety of problems in this case are rare, besides, almost complete cancellation of any research activity in today's Russia is known. And the problems are not studied enough. Therefore, the relevance of the selected topic is undoubtedly important, and we are developing it using a number of analytical and synthetic methods inherent in humanitarian knowledge. However, we also take into account the indicators of literature studies that can be appreciably helpful when working with the artistic texts of modern Adyghes writers, known and accepted at home (not in Russia, but in the republics of the Kabardino-Balkaria, Karachay-Cherkessia, and Altai) today.

\section{Literature Review}

Among the historians of the H1 XIX century, L.Ya.Lyulie, in the process of studying and generalizing the Adyghes rituals, beliefs and rites available, formed a full list of the Adyghes gods and came to the conclusion: "Hospitality, mixed with religious concepts, love of country and old prejudices, is the specific feature of the mountaineers mores, which prevents the final establishment of Islamism" [8]. Nevertheless, at the time of the savor weakening in Christianity, the Adyghes continued to persistently persuade the faith in the One God - Thae. In the XVI century, the British traveler E. Spencer carefully studied the problem, and came to conclusion: "The main postulates in the inhabitants of the Western Caucasus faith are a firm belief in one God, supreme and powerful, and in the immortality of the soul, which according to their belief will be transferred to another world, the whereabouts of their fathers. Similar to the Mohammedans, they do not represent the Divine in any visible form, but define it as the creator of all things, whose spirit is scattered throughout the outer space" [3]. In the XVII century information from the other side start to pullulate, it concerned the prevalence of Islam in Circassia. As the Dominican missionary Giovanni Lucca says about the Adyghe religion, «Some of them are Mohammedans, others follow the Greek rite, but the first prevail».

Among prerevolutionary historians, Circassian publicist Sultan Khan-Giray raised the issues of religion, especially carefully. In the final years of his life, he, in addition to the well-known "Notes on Circassia", published an essay "Faith, customs, customs, lifestyle of Circassians" [9]. In essence, it is overlapping with some chapters of the first and second parts of his work Notes on Circassia”. Sultan Khan-Giray begins to recreate in the essay Adyghes religions. Devoting an entire chapter of "Notes on Circassia" he established: "Every nation had and has more or less superstitions, and we will not spread about this subject, let us just say in conclusion that since the Mohammedan religion extension in Cherkessia, and the clergy superstition, although it increased the prejudices of the people, but gave them more philanthropic direction: no longer visible torture, or such cruel traces of a horrible delusion - orisons and talismans replaced them" [10]. The historian of Soviet times Shor Nogma wrote: "Adil Giray Atazhukin and effendi Ishak Abukov, being Mullah in his younger years, provided Sheriat between the Kabardian people, according to which criminals are all without exception (i.e. without distinction of social class), by the degree of importance of the crime, they were subjected to the death penalty and corporal punishment. The establishment of this provision has brought great benefits to the people; everyone was afraid of doing anything illegal" [11]. In a series of review works on Caucasian studies, published in the XIX century, it is necessary to put the work of the I.F. Blaramberg who is historian and archaeologist, he is considered by scientists as start scientists, who emphasized the excavations of the Black Sea coast. They were produced on the basis of artistic and historical keys, but in addition - personal impressions took place too. The work of a pre-revolutionary Russian scientist is distinguished by scientific functionality, which is analyzed by comparison approach. However, it only indirectly touches the religious attitudes and rituals of the ancient Circassians. Among the researchers of the second half of the XIX century and H1 XX century, a tangible value belongs to the works of the Kuban historian F.A. Shcherbin His works are versatile and already closer to the objective point of view, which brought science closer (after) to strict socialist realism and led away from pre-revolutionary fragmentation. In the Soviet era starts a detailed and systematic studying of the chronicle of events, ethnography, and archeology of the region. Interest for small nations increased under control of USSR Academy of Sciences. Substantial works are being published, such as "The Peoples of the Caucasus" [12, 13], "History of the North Caucasus Peoples" [14].

Modern researchers continue to be interested in the religious preferences of the Caucasian spaces. Consideration on the ethnographic background of religion questions is given to the works of currently classical Russian ethnographer-historians as Arutunova S.A., Anchabadze U.D., Alieva A.I., Bromli U.V., Gardanov V.K., Kosven M.O., Krupnov E.I., Kalmykov I.H., Lavrov L.I., Sergeeva G.A., Smirnova Ya.S., Ter-Sarkisyants A.E., Tokarev S.A. et al. Tangible contribution to the ethnographic research in relation to Adyghe made works and monographs by Mambetov G.H. "Traditional culture of Kabardians and Balkarians" [15], Mafedzeva S.H. «Adyghes: Customs and Traditions» [16], Dumanov H.M. "Social structure of Kabardians 
in the norms of adat" [17], Bgazhnokova B.H. "Circassian play" [18], Shikova T.T. "About the conditions and forms of marriage for the Kabardians in the pre-revolutionary past (late XIX - early XX century)" [19], Musukaeva A.I. "On the customs and laws of the Highlanders" [20]. Already in the post-Soviet period, in the second decade of the new century, in works published in Maikop and Nalchik by Gostieva L.K. [21], Zafesov A.H. [22], Maremshalova I.I. [23], Kagazezhev B.S. [24], Lyausheva S.A. [25] et al., aspects of the ritual culture of the North Caucasian peoples are also considered. As opposite, in particular, a modern Arab researcher (by origin - Adyghe) Khatko Fathi, which publishes already in the new century (2003) the book "Circassians and religion" motivates his scientific interest quite justifiably. As foundation he provided the as powerful stream of religiosity, in the Caucasus, in particular in Adygea: "I wanted to share my fears in connection with a new wave of Islamization in my historical homeland, because I feel my responsibility for the destinies of the youth" [8]. However, a number of modern researchers oppose this position. Thus, the author of the article "On the Notion of Mass Religious Consciousness" Z.M. Abdulagatov ascertains the opposite act of the modernity avoiding from religion: «As history shows, the general course of public consciousness development, going in the direction of a gradual avoiding from religiosity. Steep bursts of the religiosity level, taking place at certain periods of world historical development, are not of a strategic nature. Such period takes place in the modern historical process" [26].

As a basis for research, were taken works of Khuako F.N. [28-44], Hotko S.H. [45], Tlupova Z.H. [46], Shaplok G.U. [47], Siuhov S.N. [48], Sitimova S.S. [49], Pafifova B.K. [50], Marchenko R.A. [51], Mamiy R.G. and Chankaeva T.M. [52], Luchinskaya E.N and Ashinova S.B. [53], Lavrov L. [54], Kumykova T.H. [55] and others. All works are indicated in the list of literature, they served as an additional base and accompanying information for our study.

\section{Materials and Methods}

Let us turn to the key insight of the current subject - the religious consciousness, its essence and manifestations in the Caucasus and, in particular, among the Adyghes. Having a specific geopolitical level, located on the inter-civilizational flank of Eurasia, the Caucasian territory invariably attracted the attention of neighboring countries and their cultures, thus tasting their tangible action (both political and economic). Interestingly that the ubiquitous signs of ethnic groups in the Caucasus, if one does not take into account their frequent differences, are the following: the ethnic resources that exist here, if not born, were strengthened and acted in similar circumstances. It was a multi-faceted and multicultural interaction of regional nations with readiness for coming calls. And here it should be noted the frequent external initiatives that have been hovering over these mountains. Far from a complete list of countries that have periodically tried to establish power over the mountaineers of the Caucasus for centuries, we can assume, according to Khatko Fathi, the following countries: "The Roman Empire, Persia, Iran, Arabia, Byzantium, Osmania, Seljuk Turks, Mongols, Russia" [8]. The readiness that we outlined above has determined the national-religious saturation of the region that exists today. According to Adygeyan writer A.L. Makoyev, Faith is such an intimate spiritual phenomenon that it does not tolerate the presence and influence of someone else's mind and heart. The faith of each of us is a reflection of our conscience in space; this is the ratio of our three seconds of being on earth with eternity" [6]. In real, in any local culture it is permissible to find echoes of spiritual priorities that have been accumulating for centuries and containing generally accepted ideas. In fact, Christianity and Islam prevail in the North Caucasus. But, as we already noted in the introduction, the Adyghes more often refer themselves to Muslims, although they respect the teachings of Christ. For example, the leading perspicuity of A.L. Makoyev, the narrator asks and then confidently replies: "Has the world become more merciful for two millennia, following the teachings of Christ? No doubts" [6]. Islam was preceded to Adyghes in the X-XII centuries directly because of Christianity, which came from Byzantium and Georgia to the paganism that was then widespread among people, proved by folklore (including the works of M. Mizhaev, A. Shortanov, A. Gadagatly, N. Gish, etc.). Appeal to Allah, which was found at the Golden Horde, became an object of interest of Circassians already in the XIV century. Nevertheless, the universal adoption of Islam can be traced only in the XVII - XVIII centuries. In recent centuries, it is precisely makes a tangible impact on the behavioral and ideological canons of Caucasians, when it becomes quite difficult to distinguish between confessional and ethnic features. M.Z. Magomedov sees this tendency in Dagestan, Chechnya and Ingushetia as an advantage. Concerning the Circassians, one can assert that they belong to such a Muslim branch as Sunni Hanafi, and in the Adyghe Republics, the impact of Islam is markedly reduced. Before the XIX century Circassians equally comply dual faith. During the half-century of the Caucasian War, Islam was strengthened, which we consider to be the nation opposition to the coming invader who believes in Christ. In general, as can be seen, considering North Caucasus multinational space, inherent interaction as religious in general and Islamic in particular, simultaneously with the possible intersection with direct ethnicity. Today, in the North Caucasus region, there is an intense diversity of Islam as a political denomination that shows influence not only on the Russian south, but also on the existing state in general. The specificity of these branches in Islam is their relation to the canons of Islam, in the presence of specific and clearly executed ceremonies, faithful ministers and admirers. The Muslim coefficient implies not only faith and the Islamic behavioral way of life, but also a kind of political Islam (i.e., so-called Islamism), which deepens its sources in the distant chronicle. Most often, such factors have tangible qualities that permit talking about heterogeneous groups. They, like traditional social formations, have different facets in the relation of thinking in heterogeneous conditions of being.

Non-unitary attempts at national reforms in the Russian Federation have formed all possible forms of rebuff, as well as the peculiar adaptive rut in the region. In general, circumstances that are recognized in science, forging religious (in particular, Muslim) consciousness at the national level, are the following. Firstly, these are interethnic ties within the confession. Secondly, it is the interaction of religious and atheistic attitudes, and mental characteristics. Although at the same time, due to the sociopolitical and financial-economic complexities existing in the global society, it turned out that in the new century some extremist sects could enter the religious sphere.

\section{The Religious Saturation of the Caucasus}

In addition, as the contemporary philosopher M.Z. Magomedov, who has already cited above, points out, that regional religions are characterized by different saturation of national thinking. According to the cited data, related to North Caucasus, "out of the 550 surveyed respondents, 91\% referred themselves to representatives of one of the proposed confessions, $7 \%$ called themselves atheists, $2 \%$ found it difficult to choose their religious affiliation. More than half of the respondents $(62 \%)$ profess Islam, $29 \%$ - Orthodoxy, $8 \%$ - Buddhism and 1\% - Judaism" [7].

Analogous example of similar beliefs is found in the Orthodox field of the Russian Federation. So, judging by the questionnaires offered by sociologists G.M. Andreeva and L.G. Andreyeva in the first decade of the new century, $84.2 \%$ consider themselves as followers of Orthodoxy. However, when clarifying religious details, it also turns out that $7.6 \%$ of them are individually nonbelievers, $23 \%$ exclude the presence of God or are experiencing difficulties with this issue [56]. As the author of A.L. Makoev describes the religious affiliation of the author, "It is easier for a 
religious person to inspire the image of the enemy and to force destroying any opponent of his faith than an atheist. The atheist, knowing that there is nothing waiting for him, values the earthly goods too much" [6].

\section{Variants of Islam}

In the modern world, the most permissible variation of religion for Caucasian (or Adyghe) - is the normalized form of Islam. Because of its strictly expressed norm, this form necessarily corresponds to the traditional canon, like any other norm in any other sphere. The Islamic standard forms and implements the optimally possible flow of tools aimed at crossing the individual with the spiritual priorities of national chronicles and stories. As the Dagestan scholars say about the fact of the inheritance in the $21^{\text {st }}$ century, "Today religions are increasingly perceived by the peoples of the North Caucasus, as bearers of universal spiritual values, an essential element of the cultural heritage of the North Caucasian peoples [57]. Episodes like this, going through the centuries; inheritance is considered as tradition feature, which contrasts its modernist qualities today.

The faith is invariably closely united with the acting society, with its constituent mechanisms and the subjects that inhabit it Moreover, several decades ago, during the Soviet era, there was a wide application of getting rid of the religious influence of various layers of reality (both the society and the individual), i.e. actual secularization. At the time of the revolution and during the Soviet seventieth anniversary, the establishment of desecration of prerevolutionary ideals was proclaimed and strictly supported.

\section{Results and Discussion}

With the collapse of the USSR, the priorities changed radically Servants of religion, continuing the normalization of faith, clarified the specifics of the post-Soviet stage. With the absence of any ideology in the country, which covers the frequent lawlessness for two decades, has been appeared an idea to impart sacredness to all anti-religious freely and without effort. In particular, a certain religious pluralism armed with special urgency. It means indulgence in relation to the neighboring faith, or a cardinal agreement with the fact that even without faith in the Almighty, it is possible to serve for the benefit of humankind. Already in today's Russia, specifically for this purpose, the developed training cycle "Foundations of religious cultures and secular ethics" has become a tangible and noticeable mechanism that constructs the required tolerance.

Simultaneously with the favored Islamic appeals in the Caucasus, there existed components of pre-Islamic beliefs, up to this day. In this case, the formula of a harmonious mixture, described by A.L. Makoyev, applied to Adyghes as follows: "If you cannot do without religion, it is not prudent to create your own, than to use the product of someone else's mind, and follow it only. Yes, it should not be otherwise" [6]. Pagan shadows in the Circassians souls became a subject of general Adyghe attention. And that such self-created are often considered to be the general Adyghe faith, based on different religious echoes, but firmly retained in the form of the ethnic law of "Adyghe Khabze" ${ }^{1}$, accepted and strictly revered by Circassians to this day. As Khatko Fathi says today, "Now there is a great deal of civic responsibility on every person, because an uncompromising dilemma has arisen - will the people profess the primordial customs and traditions or the borrowed foreign (Arab) religious ideology and philosophy. Ultimately, this is choice that will determine and will continue to form the nation's image" [8]. And the multinational reference to the general religion is appointed by the Koran, the highest scripture. Constructed on five massive pillars, it is by thought and affairs of the ministers,

\footnotetext{
${ }^{1}$ Adyghe (Circassian) ethic-philosophical doctrine.
}

involved in the life of the heroes: "It was not the first time that Ahmet marveled at how well the mullah had managed to organize his reconnaissance", "We cannot waste time. Allah blesses our work" [5].

Recognized by the followers of Islam, the djinn spirits are divided into white and black. Among the first, undoubtedly, is included the Most High. According to A.L. Makoyev, who completely refuses to worship in quantitative terms, God can personify only "depth and purity" [6]. Or, for example, Almighty is also white energy active in works of another contemporary Adygeyan writer - novelist Aslanbek Psigusov. There are some elements that illustrate the might and power of national dominants and religions, established over several centuries. In particular, once the winners have not become accustomed to the characters begin to curse their own gods. In this impulse, they come to the fact that they are infinitely lucky: woke up, revel in the surrounding lives sometimes tiny, but confirming their own existence. That is why they are immediately taken to express their heartfelt gratitude to the gods for the mission of the god-like cover, successfully carried by the Almighty, in the process, that they continue in dairy: "This day will remain in his memory for a long time, a remnant of memories, reminding me with a heart mark that he is one of the spoils of fate, while for many of his fellow tribesmen, yesterday's sunset was the last" [58]. Consequently, a religious confession, that took place strictly after the battle, as well as directly on the sunk in the unbreakable silence. It is not definitive and irrevocable, but more individually. The frustration in faith of A.P.Psigusov clearly echoes the possible mood of A.L. Makoyev, in a similar statement. Here the narrator is closer to reality, but also looks back at the Most High: "Why I cannot fit into the usual framework of life - everything takes me into outer space. In fact, I'm doomed from birth. If I had done what I had to do according to my talent, I would have burned it in a moment. But by my inaction I deceive Providence. He is expecting something from me, and I shamelessly make promises every time, I swear that $\mathrm{He}$ did not make a mistake in me and I gain time. Do I win for what?" [6].

Among the Circassians there was faith in the djinn. And no less mentioned among modern Adyghe authors along with white djinns- black mystical characters. Thus, the devotion of the devil by Circassian writer Asker Yevtykh, who wrote mostly in Soviet times, was particularly active, and therefore produced the only sacred word saturated in socialist realistic literary language. Indignant in his novel "Heart Break" [59], one of our fellows: a military ground, overgrown with grass: "Good grass, Deuce takes it!!" [54, p. 9]. In addition, already on the following pages, when talking about "intelligent namby-pamby» $[60$, p. 10] or about a similar glass grenade bottle $[59$, p. 11] - the same phrase «Deuce take it!" It is also used in the subsequent author's text [59, p. 31], etc. There is also another standard mention of the devil: "Go away! Go away! - Ilyinichna used to say, expelling the God knows where came from mosquito..." [59, p. 19]. And the situation varies in severity. Similar vocabulary is possible in episodes - dialogues of serious characters. These way two interlocutors discuss the third person. One of them leads to a character trait, such as understanding. To this, the second one responds with an assessment: "What is for devil's sake understanding is?" [59, p. 20]. The author also uses such active phrases in the Russian colloquial style as "where the devils are" [59, p. 31] and "disappear to hell" [59, p. 52]. Thus, on the first 50 pages of the author's text of Asker Yevtykh, who created, it seemed, in the strict canons of Soviet realism, 7 references to a religious villain. Indeed, Sartre calls him "Satan" and defines it very peculiarly, "a symbol of disobedient and inflated children, demanding that the paternal view helps them to stiffen in their particular essence, and who commit Evil in the framework of Good for the sake of affirming and sanctifying their own particularity" [60].

Or again, in A.L. Makoyev's " Zul story" the description of one of the popular Aulian stories concerning the local fortune-teller, cannot be without an evil one The old woman who had risen in the dark and slipped for no reason at all, was killed under strange 
circumstances, when the village forester, chasing a black cat, finally managed to kill the importunate animal: "The attack of the dark forces is not far off, it is necessary to prepare for the invasion, and wooden paddles of forester Tuna will not fight them back" [61]. Here it should be emphasized that in general fortune-tellers and witches are also quite popular among the Adyghe authors today. And this fact can be considered explainable, since the Adyghe chronicles contain extensive information about the Adyghe faith. Sources of similar publications (including scientists) confirm and prove that both in their circles and in their ranks the regular and valid technology of fortune telling is similar to the Romans. And because of this fact A.A. Khagurov, can calmly and confidently introduces the fortunetelling sacrality today, in the person of the witch Khaniya in his story, allowing his characters to intersect with her in their actions and desires. Thus, the narrator hero sees in himself a five-year-old boy, which helps him to remember, with a kind word, a strange old woman living next to her: "But there remained the house of the old woman Khaniya that was opposite to the grandfather's house. Khania was considered as a sorceress in the village. Wise Aslambiychik knew what he was doing: I was not a relative of the witch Khani, but I was her neighbor, so for her "friend". The window from the inside was curtained with matting" [1]. It should be noted that such mysterious old women are not too rejected; sometimes they are even attractive on book pages. There was a popular version that some Adyghes turned out to be husbands of female djinnes, which were considered to be extremely exquisite. Modern Adyghes are endowed with the epithet "witch"(in Adyghe language - "Ud") in relation to visionary, sensible women. It was believed that " $U d s$ ", there is a sorcerous gathering that was carried away by dark magic and thereby brought misfortunes to fellow countrymen. Nevertheless, few people believed that they were wiser than a man, and therefore the Adygeyan proverb says: "People know that, what Uds don't". Representatives of the nation were also sure that water witches (more precisely, mermaids) lived in the grassy thickets on the river coasts. According to the ordinary Aulian version, those were blue-eyed and long-nail blondes, who could have been taken home and patronized by fellow tribesmen.

A tangible place in the course of development of the story line in the above-mentioned A.Kh. Psigusov also belongs to the black mystic. However, the acting here shaman acts very nobly and saves a life to a number of positive characters. Available interior items contribute in these, for example household items and buildings that come across him on the road. The metaphorical turns used by the author in combination with a mystical fuse, create the mythical character required in the postmodern novel The door, under which "damp earth" is doused with a thoughtful hand, is "obediently opened" under the mighty pressure of a hurrying shaman to help when the bright sun rays shine through the gloomy structure, giving the tired slaves a bright aspiration really embodied with his arrival.

Expressive write of modern Adygeyan writers, related not only to the devil and his partners, but also ministers of the Most High. Religious ministers here reproduce with equal frequency, both in positive and in negative mean. Opposite to this, religious minister at M.I. Kandur work, countrymen consider it truly sacred: "Local residents regarded this as a sign of God himself. No doubt, after this Ushurma acquired a tremendous authority from these superstitious people. They are convinced that he is sent from above to guide them" [5]. It is historically known that in the early days the Adygeyan were mostly religious people on the Muslim path, that is, mullahs, cadis, mostly were people of Turkish nationals. As a consequence, Islam strengthened the will and power of the Turkish-directed branch of the aristocracy. Researchers often focus on the integrity of Islam, but, at the same time, - and on its versatility as a social phenomenon. In general, several characters are also active in the faith of the foreign Adygea M.I. Kandur in his trilogy "The Caucasus", where the decoration and design of the mullah's dwelling are clearly combined with his professional way of life: "Everything here breathed with strictness, combined with the deep religiosity of the master" [5].

And this severity is often inherent in descriptions of religious figures also in works of other authors. So, likewise, the church ministers of A.H. Psigusov ("Biographies ...") are modest in preferences. In the final part of the second chapter, two servants of the regional church who went to the hail, strolling around the bazaar and examining the shop windows in the process of communication, evaluate the wealth to themselves. Reacting to the desire stated by the interlocutor by the will of the case to buy a two-floor house one of them is confused. He stresses that he would like to experience poverty with tranquility, than assuring his colleague, declaring: "I am a pious and unassuming person" [58]. The same line of modesty of desires continues simply in descriptive pictures (both individuals and actions). For example, in M.I. Kandura, mullah is described mainly by a rod physical sign a "falling beard" covering all the others, up to the age. And the manner of religious hero behavior acts as a kind of proband for further plot turns: "His eyes glittered, but all the movements of a large body were slow and careful. The remaining elders of the village were located in the seniority next to him. There was also Hamzet, he lay on pillows and was very pale. The old men heatedly discussed something, and the mullah sat detached, halfclosed his eyes and silently whispered his prayers to the beard" [5] In this way, the author paints a portrait of a gracious hero describing a picture of the actions of a group close to the mosque. In addition, there are identical episodes in the descriptions in works of other authors, which were analyzed by us. Thus, A.L. Makoyev ("The History of Zul") in the peacefully living aul believers consider it their own duty to assemble and observe the procedure: "Religious people, during the day, gathered at the mosque to ask Allah to curb the mad people, return their minds and return to their old life" [61]. Or at M.I. Kandur "All the soldiers gathered in the village square in front of the house of the mullah for prayer" [5].

In general, ritual procedures can be called sufficiently revered by Adyghes throughout many centuries-old chronicles. So, in particular, during the awesome thunder, Adyghes were singing a special song. Once a year, the day of the first lightning was celebrated as a holiday. Anyone killed by lightning was equated to be marked with good. He was buried with the exact observance of the coordinates of the incident. At the same place for a long time, during the week, there was an intensive pyro (including sacrificial, and dance) procedure. Not so long, but no less intense was the three-day procedure for commemorating the animal that died from the lightning. Also, it was revered sanctified tree, affected by lightning. It in the minds of the Adyghes was immediately gifted with curative qualities.

In general, revered tree rituals from time immemorial and to this day function in the Adyghe environment. So, for example, M.I. Kandur, "The area where they lived was covered with a dense forest and, as the ancient traditions of the Circassians told us, many of their gods and goddesses lived in these forests [5]. Similar, the forest massifs, described by the author here, stood for centuries, sometimes, in the middle of the $19^{\text {th }}$ century. - in the form of original Sacred Groves, holding on their trunks for decades and even centuries sometimes the invaluable outfit of folk-revered heroes. Here also could be located sums with the ashes of the heroes. Adyghe researchers are inevitably interested in the attitude of the representative of the nation to the tree as a symbol. As one of the most recent and most multifaceted researchers K.H. Unezhev points out, the classification of trees for the Adygea consisted in associating with good and evil, depending on which the researcher forms lists - delivering happiness and giving misfortune. To the first category of gentile breeds, the Adyghes included fruit varieties. That's why it was strictly forbidden to cut down a pear and mulberry tree. The man had to plant twelve fruit trees and only then had the right to create a family. "Good", or "happiness bringing" were admitted such trees as linden, oak, ash, and hawthorn. It was believed that hawthorn 
possesses a magical power to drive out unclean force, to protect people and animals from spoilage and slander. To the "unkind trees" belonged to the representation of Adyghes and Balkars such trees as cornel, maple, wild cherry and others [62]. He who came to the mountains in ordinary circumstances always had the opportunity to refresh himself, since he was already taken care of by fellow countrymen who had been there before. They were obliged to leave the third part of the harvested crop in the trees, and as they fell down they entered the diet of the forest dwellers, i.e. the beasts.

However, some of the authors considered today do not much respect the religious procedure. The logic of veneration of the Almighty, the same writer argues his own accusations against pagan rituals, promises made in honor of the heavenly deities. In the view of A.L. Makoyev, already in another work, "The Returned Skies," the inconsistency of ceremonial procedures is obvious: "So many times to do prayers, fasting for so many days in a certain order and certain food, etc. In itself, there is nothing wrong with this, but getting carried away by them, a person imperceptibly substitutes the depth and purity of the exercises in order and quantity" [6]. A common version of the spread of Islam is the option of consolidating the spiritual tradition that came from the great-grandfathers, which, apparently, predetermines the corresponding concept. With regard to Islam in the Caucasus, the definition of "traditionalist" is often used.

This happened without an avoiding from a whole range of previously adopted family and tribal attitudes with the consolidation of the Islamic essence behind them. At the same time, the beliefs and rituals adopted by Muslims to some extent turned out to be in unison with people's similarly philanthropic procedures. For example, they confront the evil spirit of the Circassians by means of a talisman, a certain prayer, written out by the attendant of the mosque on paper (sometimes - a scrap) and tied in a mini bag (cloth or leather) with three or four corners. In the form of amulets guarding against diseases, a piece of cloth with oak chips formed by a lightning strike into a tree was worn on the individual's neck. In addition, fragments of such rags were threaded on a branch in the form of an offering. As a result of these national and religious confessions, not only the admirer of the Most High, but also a convinced atheist in the Caucasus can recognize the most visible rituals in the family and everyday life of the people. This is also traced by sociologists. In particular, the above-quoted Dagestan scholar Z.M. Abdulagatov on the ritual procedures states the following. Judging by his surveys, in the Republic of Dagestan, Kabardino-Balkaria Republic, and Chechen Republic there are $3.3 \%$ of non-believers "participate in all religious rites and attract others" and 43.3\% "sometimes participate in some ceremonies." Muslim rituals of marriage, funeral, sunnat, naming, by the national in content and religious only in form, but because of all consider $44.0 \%$ of the polled three of these republics. The exclusively religious, sacral character of these rituals is noted only by $36.9 \%$ [11]. As can be seen from the purposeful predetermination of the above rites, this tendency mainly concerns concrete, more frequent in everyday life procedures. They, in turn, are sometimes not only admirers of the Most High, but also secular atheists are presented as a centuriesold family treasure. In particular, the ordinary modern Adyghe, distraught with the death of a loved one, will not forget to turn to the mosque to call her servant, who possesses the skills required for the ablution of the deceased. Either on the pre-trial day, the procedure in the registry office is preceded by the ritual "nachah" that takes place in the mosque and consists of writing (in front of everyone) each of the married couple of words. And a friend of one of them will definitely come to stand beside him and share the joy not only in the state institution, but also in the mosque (in which he probably never was). But it is so necessary, so did the elder brother, - means, it is necessary to me. This is the law.

Z.M. Abdulagatov calls such confusion "religious instrumentalism", maximally expanding it at the same time: "This phenomenon, when Islamic values are used, function among a part of the population not only for expression and achievement of sacred values, goals, and others - non-religious, social" [11]. In fact, the North Caucasus allowed the crossing of the normalized religion with regional ethical matter of various ethnic groups. As a result, a peculiar territorial configuration of its functioning was formed, based on the world's Muslim dogma, but not always understood by our fellow countrymen: "In silence, Ahmet thought that his heart was beating incredibly loudly, he hardly suppressed the desire to jump into the saddle without waiting for the end of the rite" [5]. But other motives that stimulate the tradition of ancestors are more powerful. As Z.M. Abdulagatov believes, these are the "right actions" in life, regardless of belief in Allah. This scientist argues the current conclusion with concrete sociological data. "So, out of five answers to the question" Who, in your opinion, can be called a believer? ", The largest number of respondents chose the position" A true believer is one who commits morally correct acts in life, and does not swear in the faith of Allah and fulfills other requirements of the Islamic religion "(32.6\%)" [56].

\section{Conclusion}

As a result, chronology and the current state of phenomena in the North Caucasus allow us to come to certain conclusions. First, this is the fact that both religions common today (Christianity, Islam) are not at all sources of interethnic difficulties. Moreover, they at one time managed to settle them to some extent and settle interethnic conflicts. The connections existing today in the national republics between ethnic groups can be designated as constant and stable, which can have a tangible impact on maintaining a stable tolerance. Secondly, we consider it inevitable that the state must strive to support the existing religious branches (in particular, Islam and Christianity).

\section{References}

[1] Harugov AH, Crossing: Collection of short stories. Krasnodar: KubGAU, 2014.

[2] Capitsa SP. I am a Russian, Orthodox atheist. http://orthodoxy.cafe/index.php?topic $=555546.0$

[3] Spenser E, Travel to Cherkessia. Maikop: RIPO Adygea, 1839.

[4] Lopatkin RA (2003), Religiosity. Sociological Encyclopedia 2.

[5] Kandur M, CAUCASUS: historical trilogy. Moscow: Kandinal, 1994.

[6] Makoev AL, Returned sky: Stories. Nalchik: Elbrus, 2015.

[7] Magomedova MZ (2010), Religious identity in the North Caucasus. Islamovedenie 3.

[8] Fathi Kh, Adyghes and religion. Maikop: GURIPP, 2003.

[9] Han-Girei S (1842), Faith, customs, customs, lifestyle of Circassians. Russkiy vestnik 1.

[10] Han-Girei S, Historical and ethnographic composition of "Notes on Circassia". 1836

[11] Nogmov Sh. Religions of Adyghes.

[12] Kosven MO, Lavrov LI, Nersesov GA \& Hashaev HO (eds.), The Peoples of the Caucasus. Vol. 1. Moscow: USSR Academy of Sciences, 1960

[13] Gardanov BA, Guliev AN, Eremyan ST, Lavrov LI, Nersesov GA \& Chitay GS (eds.), The Peoples of the Caucasus. Vol. 2. Moscow: USSR Academy of Sciences, 1962.

[14] Narochnickij AL (ed.), History of the North Caucasus Peoples. Moscow: USSR Academy of Sciences, 1988.

[15] Mambetov GH, Traditional culture of Kabardians and Balkarians. Nalchick, 1998.

[16] Mafedzeva SH, Adyghes: Customs and Traditions. Nalchik, 2000.

[17] Dumanov HM, Social structure of Kabardians in the norms of adat Nalchik, 1990

[18] Bgazhnokova BH, Circassian play. Nalchik, 1991.

[19] Shikova TT, About the conditions and forms of marriage for the Kabardians in the pre-revolutionary past (late XIX - early XX century). Nalchik, 1956.

[20] Musukaeva AI, On the customs and laws of the Highlanders. Nalchik, 1986. 
[21] Gostieva LK (1998), Traditsionnye konflikty i obychnoe pravo v kolkhoznoj derevne Severnoj Osetii (po arkhivnym materialam LK Gostievoj) [Traditional conflicts and customary law in the collective farms of North Ossetia (on archival materials of LK Gostieva]. Institute: "Otkrytoe obshhestvo"

[22] Zafesov AH (1968), Iz istorii konevodstva u adygov [From the History of the Circassian horse and adyg]. Uchenye zapiski Adygejskogo nauchno-issledovatel'skogo instituta jazyka, literatury $\mathrm{i}$ istorii, 8. [Notes of the Adyghe Scientific Research Institute of Language, Literature and History]. Maykop, 8, 79-91.

[23] Maremshalova II (1999), Problemy issledovaniya ehtnicheskogo soznaniya i samosoznaniya. Sovremennaya ehtnopsikhologiya: khrestomatiya Проблемы исследования этнического сознания и самосознания. Современная этнопсихология: хрестоматия [Problems of research of ethnic consciousness and identity. Modern ethnopsychology: anthology]. Мн.: Харвест, 92-134.

[24] Kagazezhev BS (1999), Problemy iskusstva i ehtnografii [Problems of art and ethnography]. Maikop: Adygeya State University.

[25] Lyausheva SA (2002), Evolyutsiya religioznykh verovaniy adygov: istoriya i sovremennost' (filosofskokul'turologicheskiy analiz). [The Evolution of religious beliefs Circassians: Past and Present (philosophical and cultural analysis)]. Rostov-on-Don.

[26] Abdulgatov ZN. (2016). About the concept of mass religious consciousness. Sotsiologia i upravlenie 2(3).

[27] Khuako FN, The life of the new century in the minds of Adygeyan and surrounding authors. Lambert Academic Publishing, 2016.

[28] Khuako FN, The view of the Caucasus "from within" in the new prose. Stredoevropsky Vestnik pro vedu a vyzkum. Belgorod: Belkniga, 2015.

[29] Khuako FN, The cycle of life. Stredoevropsky vestnik pro vedu a vyzkum. Belgorod: Belkniga, 2015.

[30] Khuako FN (2012), The embodiment of the concept of ethnoconsciousness in modern Adygeyan novelistic. Proceedings from VIII International Conference: Days of Vedas. Publishing House «Educatíon and Science».

[31] Khuako FN (2013), Humanitarian Adygea in the consideration of the general ethnic problems. Proceedings from IX International Scientific and Practical Conference: Education and Science without Borders-2013. Prezemisl: Nauka i studiya.

[32] Khuako FN (2016), The acting person of history in the Adyghe prose of the past and new centurie. Bulletin of the Adyghe State University. Filologiya i isskustvovedenie 2.

[33] Khuako FN, Spiritual values in the modern multinational society of the Russian Federation. Publishing House «Education and Science», 2014.

[34] Khuako FN, The Swan Song of Asker Yevtych. Stredoevropsky Vestnik pro vedu a vyzkum. Belgorod: Belkniga, 2015.

[35] Khuako FN (2011), Some questions of ethnic self-identification of Adyghes. Proceedings from VII International Scientific and Practical Conference: Dynamics of scientific research.

[36] Khuako FN. (2016). Postmodern methods as a note of harmony of Western (U. Eco) and Adyghe (A. Makoyev) literatures today.

[37] Khuako FN (2015), Freedom of religion and the possibility of its manifestation in Sochi. Proceedings from International Scientific Practical Conference: The Scientific Potential of the World. Sofia: BYAL GRAD-BG OOD.

[38] Khuako FN (2013), The modern Caucasus in the artist's presentation of an eyewitness. Proceedings from International Scientific Practical Conference: Proceedings from International Scientific Practical Conference. Prezimisl: Nauka i studiya.

[39] Khuako FN (2014), Modern crime of Russia from the point of view of the modern Adygeyan author. Proceedings from the 10th International Scientific Conference: Dynamics on the Timetable of Science. Sofia: Bial GRAD-BG Ltd.

[40] Khuako FN (2015), Sultan Khan-Giray in a new perspective. Stredoevropsky Vestnik pro vedu a vyzkum. Belgorod: Belkniga.

[41] Khuako FN, The tsar's work of the ancient Adyghes. Lambert Academic Publishing GmbH \& Co, 2012

[42] Khuako FN (2012), Ethno-Consciousness as an Integration Factor of North Caucasian Artistic Creativity in the New Century. Caucasiologic Papers Caucasian Search (in English, Arabic, Russian). Tbilisi.

[43] Khuako FN (2014), Le Tendenze Della Proza Di Adygea Del Nuovo Secolo. Italian Science Review 4(13).

[44] Khuako FN (2014), Priority in the New Century Media on the PrActivity in South Russia. Proceedings from International scientific and practical conference: Science and Education. Vol. 9.
Philological sciences. Political science. Sheffield: Science and education LTD.

[45] Hotko SH (2016), The integration of Abazin into the political space of Cherkessia. Bulletin of the Science of the Adyghe Republican Institute of Humanitarian Studies named after TM. Kerasheva 8(2).

[46] Tlupova ZH (2017), Revival of moral values in the younger generation on the example of works by T. Kerashev. Bulletin of the Science of the Adyghe Republican Institute of Humanitarian Studies named after TM. Kerasheva 11.

[47] Shaplok GU (2017), Zy ored ihish. Bulletin of the Science of the Adyghe Republican Institute of Humanitarian Studies named after TM. Kerasheva 11.

[48] Siuhov SN, Features of the formation of prose on the "modern theme" in the Adygeyan literature of the 60s-80s. Maikop: AGU, 2016.

[49] Sitimova SS (2017), Dialectical neighborhood: Bzhedugi, Kuban Shapsug. Bulletin of the Science of the Adyghe Republican Institute of Humanitarian Studies named after TM. Kerasheva 13.

[50] Pafifova BK (2017), Ethnopedagogics as a source of formation of the cultural-value nucleus of personality. Proceedings from 13th International Academic Conference: Applied and Fundamental Studies.

[51] Marchenko RA, Mythologization of mass consciousness in the sociocultural dynamics of our time. Maikop, 2016.

[52] Mamiy RG \& Chankaeva TM (2016), From analysis to historical generalization. Bulletin of the Adyghe State University. Filologiya $i$ isskustvovedenie 2, 164-170.

[53] Luchinskaya EN \& Ashinova SB. (2017). Appeal as a verbalization of family relations in Russian and Adygeyan tales. Proceedings from II International scientific and practical conference of young scientists (doctoral students, graduate students and undergraduates): Topical issues of modern philology: theory, practice, development prospects, 78-81.

[54] Lavrov LI (1959), Pre-Islamic beliefs of Adyghes and Kabardians. Researches and materials on the problem of primitive religious beliefs. Works of the Institute of ethnography of N.N. MiklukhoMaklay. A new series 51, 193-236.

[55] Kumykova TH, History of the people of the people of Adygea: Compiled according to the traditions of the Kabardians. Nalchik, 1982.

[56] Andreeva GM. \& Andreeva LK. (2010). Religiosity of student youth. The experience of comparison with the religiosity of Russians. Sotsiologicheskie issledovaniya 9.

[57] Ismailov ASh, Hanbabaev, KM \& Ragimov AA, Religions in Dagestan: history and the current state. Makhachkala: Dagestanskoe knizhnoe izdatelstvo, 2007.

[58] Psigunov AH, Biographies of thirty Hittite kings. King Hatti Pithana. Nalchik: GP KBR, 2005.

[59] Yevtykh A, Heart Break. Moscow, 2003

[60] Batai Zh, Theory of religion. Literature and Evil. Minsk: Sovremennyi literator, 2000.

[61] Makoev AL. History of Zul. 2015.

[62] Unezhev KH, Culture of Circassians (Circassians) and Balkarians. Nalchik: El-fa, 2003. 